\title{
實驗的膀胱結石の偏光顯微鏡的並にX線廻折的研究
}

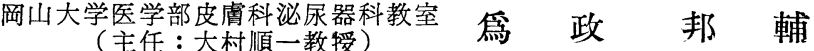

\section{STUDIES ON EXPERIMENTAL VESICAL CALCULI BY POLARIZING MICROSCOPE AND X-RAY DIFFRACTION METHOD}

\author{
Kunisuke Isei, M.D. \\ From the Department of Dermatology \& Urology, \\ Okayama University Medical School, Okayama \\ (Director: Prof. J. Omura)
}

The studies were made on a series of rats with foreign bodies placed in the bladder and the incidence of calculous formation was observed by polarizing microscope and, moreover, the same experiments were made on rabbits and analyzed by X-ray diffraction.

The influence of glucuronic acid upon calculous formation was also studied on rats.

(1) Struvite $\left(\mathrm{MgNH}_{4} \mathrm{PO}_{4} \cdot 6 \mathrm{H}_{2} \mathrm{O}\right)$ was observed alone when the fragment of magnesium ammonium phosphate was used as nucleus. When calcium oxalate was used as nucleus, the components of the foreign bodies stones and all other daughter stones were Newberyite. And also, on the cases of uric acid stones, all of them were dissolved, but Newberyite were produced in a few samples.

(2) Calcite was the main component on rabbits vesical calculi, but Struvite was also observed on the case of silk gut nucleus.

(3) The formation of foreign bodies calculi of bladder in rats was prevented by the administration of glucuronic acid, but no effective influences could be expected on human urinary calculi which were used as nuclei.

\section{（本研究は文部省科学研究費による）}

\section{I 緒 言}

実驗的異物膀胱結石により尿石形成に対する諸因子を 解明せんとする試みは Vermeulen ${ }^{1)}$ 等の系統的研究の 他，最近本邦においても森 ${ }^{2}$ ，加藤 ${ }^{3)}$ 等の報告がある. これら異物を核とする膀胱結石形成実驗は続発性結石で ある䉆，その実驗成績を以て真の結石形成に対する原因 を云くすることは不適当との考えもあるが，既に別稿4 において述べた如く，人膀胱結石においては上部尿路に おける結石或はその小片が膀胱に落下したものを核と し，それに諸種の因子が加わつて発育成長せるものが多 いこ推察され，從つてそれら上部尿路よりの結石の膀胱 内における発育成長は，必ずしも上部尿路結石と同じで はなく，寧ろそれら結石を核として別様の発育が行われ るものと推察出来る構造を見出したものが多い. 即ち單 純に続発性結石として膀胱結石を考えるには餘りにも多 くの問題があり，やはり結石生成の本質に関聯した諸因
子が考えられるのであつて, 根本に結石形成因子が存在 するとはいえ，か〉る上部尿石或はその破片は膀胱にと つては一種の異物であり，，亦〉る考えょりすれば膀胱 結石の多くは異物結石とも謂うことが出来よう。

実驗方法の如何によらず，実驗的に形成された結石が 人尿結石と比較研究出来るかどうかは本質的に重要且つ 難かしい問題であるが，案外等閑に附されている感があ る。私は実驗的異物膀胱結石，特に人尿結石片を使用す る場合の発育形成狀態を観察し，又それを人膀胱異物結 石の構造と比較してみるととは上記の本質解明の一助己 なると思い，ラットの膀胱に人尿結石片を押入しその異 物結石形成の狀態安偏光顯微鏡的に観察すると共に，形 成結石につきX線粉末写真法により分析を行つた. 一方 結石形成阻止乃至溶解作用安解明せんとして，グルクロ ン酸を使用し, 膀胱結石形成に関する因子に考察を加え た. 
実験的異物膀胱結石の偏光顕微鏡写真

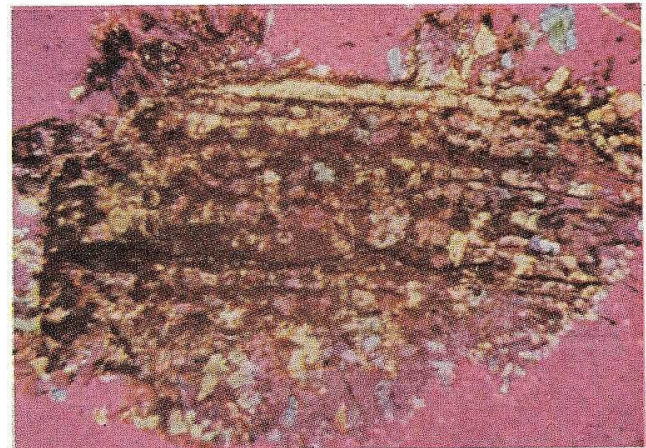

$\mathrm{MgNH}_{4} \mathrm{PO}_{4} ・ 6 \mathrm{H}_{2} \mathrm{O}$ 結石片を核とせる もの

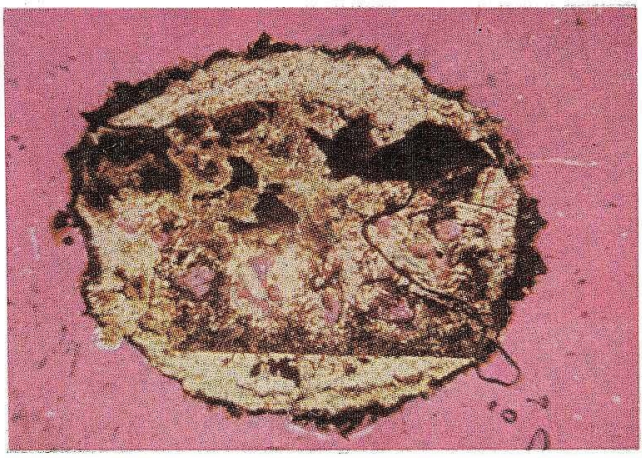

$\mathrm{CaC}_{2} \mathrm{C}_{4} \cdot \mathrm{H}_{2} \mathrm{O}$ 結石片在核とせるもの

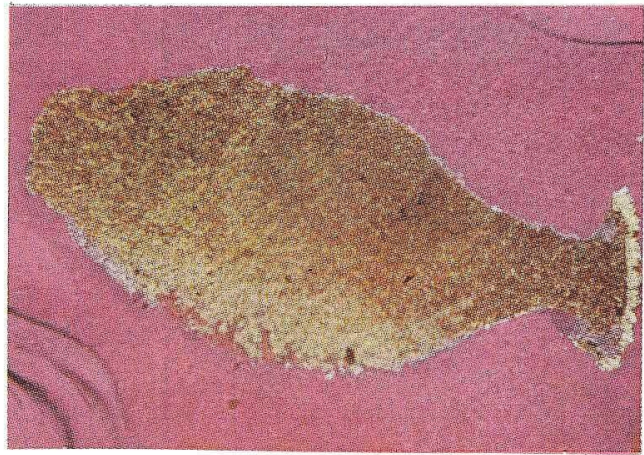

尿酸結石片が半ば溶蝕されている

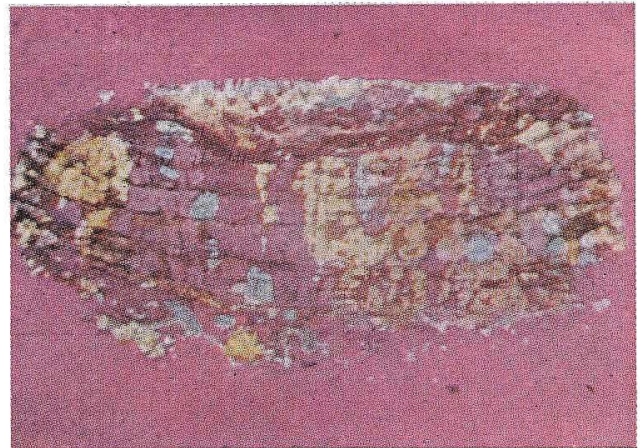

$\mathrm{MgNH}_{4} \mathrm{PO}_{4} ・ 6 \mathrm{H}_{2} \mathrm{O}$ 結石片を核とせる あの、グルクロン酸投与例

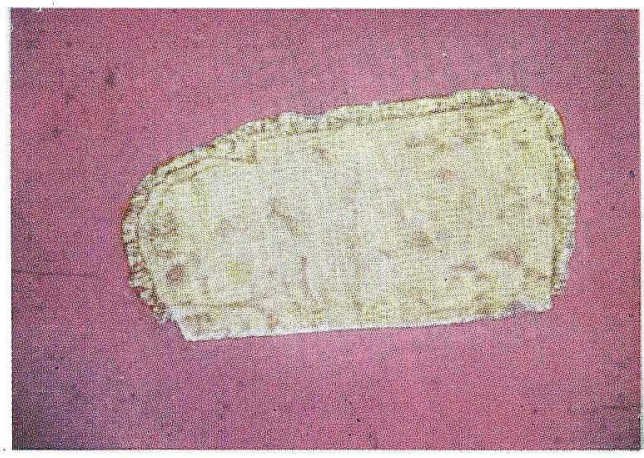

$\mathrm{CaC}_{2} \mathrm{O}_{4} \cdot \mathrm{H}_{2} \mathrm{O}$ 結石片を核とせるすの グルクロン酸投与例

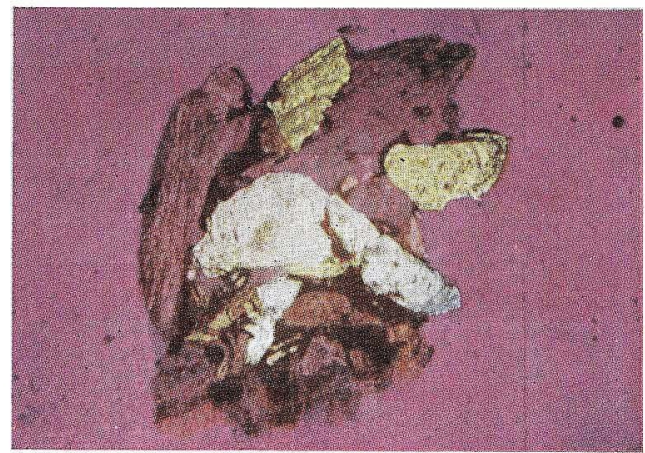

姉妹結石 
實驗的膀胱結石の $\mathbf{X}$ 線粉末寫眞
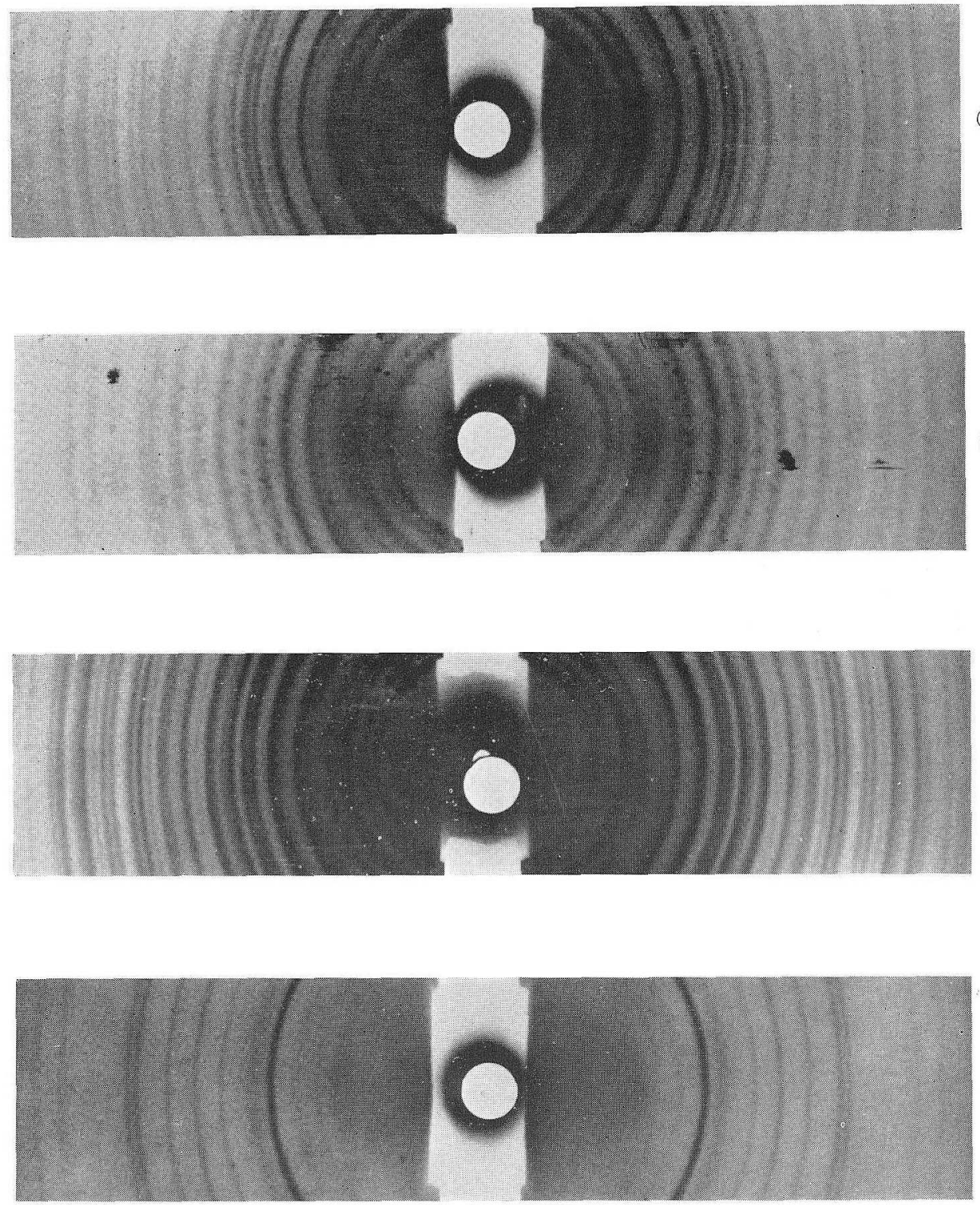

(2)

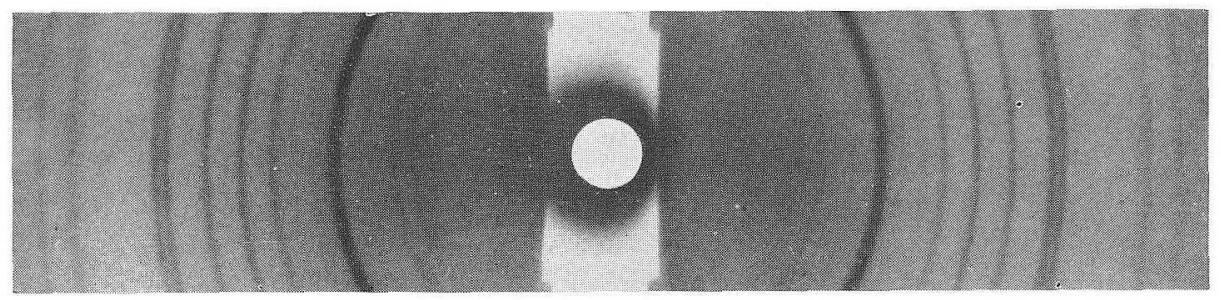




\section{II 研究方法}

実動実驗の方法は森 ${ }^{3)}$ ，の方法に準據して行つた。即 ち動物は雄性ラット（150〜 $200 \mathrm{~g} ）$ を用い, とれを 3 群に分与, 核としては别稿 $\left.{ }^{4}\right)$ に偏光顯微鏡的観察を行 つた膀胱結石の中より $\mathrm{MgNH}_{4} \mathrm{PO}_{4} \cdot 6 \mathrm{H}_{2} \mathrm{O}, \mathrm{CaC}_{2} \mathrm{O}_{4} \cdot \mathrm{H}_{2} \mathrm{O}$, 及び尿酸の 3 者を主成分とするむのを選び，夫ふヤスリ にて直俓 $2 \sim 3 \mathrm{~mm}$, 厚さ $1 \mathrm{~mm}$ 前後の円板とし, 構造上な るべく同じ部を使用した。 これら結石片は塩化カルシウ ムデシケーター中で乾燥し, 化学天秤で秤量, 24時間へ ニシリン液（10cck10万單位を含む）に浸して使用し た. 実驗食はオリェンタル䤉母社製の $\mathrm{M} ・ \mathrm{C} ・ \mathrm{R} 5$ を用い ( 1 日 $15 \mathrm{~g}$ 平均), 被驗動物の半数に $0.2 \%$ D-グルク ロン酸（中外製藥グロンサン）水溶液として給水瓶によ り與えたが，1 日の攝水量は平均 $20 \mathrm{cc}$ に止まつた。

結石插入に当つては, エーテル麻醉を行い, 剃毛後, 沃丁及び次亞硫酸アルコールにて清拭し, 膀胱高位切開 の方法にて核を扱入し, 上記結石片を 1 二宛扱入後, 絹 系にて膀胱壁, 腹筋, 皮㼺を別々飞縫合し, 手術創飞は ペニシリン液を撤布した。

飼育期間は 6 週間とし，実驗期間中の尿路の感染を防 ぐ目的にて二基ペニシリン（バイシリン）を 1 匹につき 毎週 1 包 5 万單位宛服用させた. 結石插入前, 挿入 3 週 後及び 6 週後に尿のpHを測定した．尿は動物を把持する 際に排泄する自然尿によつた。 6 週間後にェーテルで殺 し, 膀胱内容について Krystensen の尿素培地（寒天を 除く) 用い培養を行い，尿素分解菌感染の有無を检し F.

摘出した尿石片は軽く水洗後, 塩化カルシウム・デシ ケーターで乾燥科量した．この際に尿素分解菌感染の認 められたものは，插入結石片と共に多数の姉妹結石が生 じ，又感染の見られない動物にても多少の姉妹結石が生 じたので，插入結石片をは別個に科量した。かっる異物 結石及び姉妹結石について，人膀胱結石の偏光顯微鏡的 研究に抢けると同様の方法により, 薄片標本を作製し, 偏光顯微鏡的に観察すると共にX線粉末写真法により形 成異物結石の決定を行つた。

\section{III 研究成綪}

1. ラツトに怙ける異物膀胱結石並lグルクロン酸に 上る発育阻止

$\mathrm{MgNH}_{4} \mathrm{PO}_{4} ・ 6 \mathrm{H}_{2} \mathrm{O}$ 結石片を核とせるもの (Fig. 1) そ执いては，使用ラット 5 匹中，すべてに結石を生じ， 内 1 匹は揮入後 26 日で死亡した。

その異物結石は $\mathrm{MgNH}_{4} \mathrm{PO}_{4} \cdot 6 \mathrm{H}_{2} \mathrm{O}$ を主成分とし, 核
結石表面に連続して発育し, その結晶㤥である $\mathrm{Mg}$ $\mathrm{NH}_{4} \mathrm{PO}_{4} \cdot 6 \mathrm{H}_{2} \mathrm{O}$ の結晶と関係があるように見えるものが あつたが確定的なことは云えない。ただ標本上に柇いて は, 核結石上に明膫な非晶質样物質の層は認められな い.

グルクロン酸を投與した 5 匹においては, 著明に異物 結石形成を阻止しているのを認めたが(Fig. 2 ), 核結石 たる $\mathrm{MgNH}_{4} \mathrm{PO}_{4} \cdot 6 \mathrm{H}_{2} \mathrm{O}$ そのものに対しては明膫たる溶 解は認められなかつた。 たが一部の核結石に掞いて多少 溶解の痕跡を認めたが, グルクロン酸投與群と非投與群 における異物結石形成の狀態にはなんらの差異を認め得 なかつた・

尿酸結石片を核とせるもの (Fig. 5) においては 5 匹 中 3 匹注 6 週後, 捚入核結石は溶解 (乃至排出) され, 僅か 2 匹に薄い結石片を少量認めたが, この溶存結石片 と思われたものも，X線粉末写真法を行つて及ると， $\mathrm{Mg} \mathrm{H}\left(\mathrm{PO}_{4}\right) \cdot 3 \mathrm{H}_{2} \mathrm{O}$ (Newberyite) であり, 從つて尿酸 結石の溶存片ではなく, むしろ姉妹結石の部類に入れる べきものと思われる. 実驗途中死亡したラット 1 匹の尿 酸結石片を檢する己 Fig. 5の如くであり，核結石插入 26日で凹紸狀に溶蝕されているのを認める. 恐らく尿酸 結石片の溶解が, かなり速やかな爱に異物結石形成が起 り難いものと考えられる。

第 1 表 ラッテ膀胱異物結石における グルクロン酸の影響

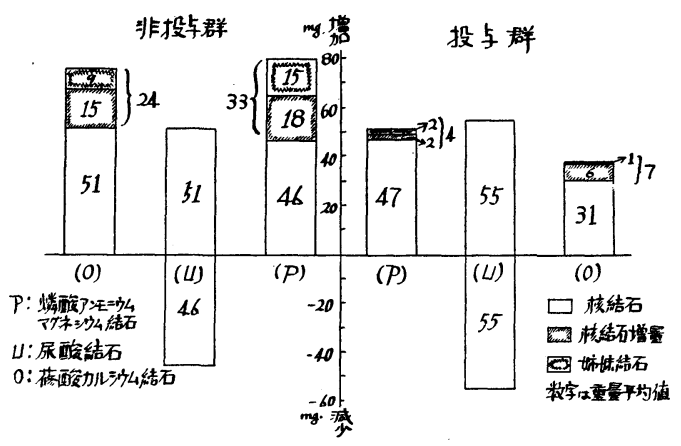

グルクロン酸投與の 5 匹に标いては，完全に溶失し， 又姉妹結石発生は全く認めなかつた。

$\mathrm{CaC}_{2} \mathrm{O}_{4} \cdot \mathrm{H}_{2} \mathrm{O}$ 結石片を核とせるもの (Fig. 3) 飞打 いては 5 匹中 4 匹に異物結石及び姉妹結石を生じ, 内 1 匹核結石㨉入後 7 日で死亡したが, 結石表面が薄い有 機性の被膜で蔽われているのを認めた。異物結石は Mg$\mathrm{H}\left(\mathrm{PO}_{4}\right) \cdot 3 \mathrm{H}_{2} \mathrm{O}$ であつたが, $\mathrm{MgNH}_{4} \mathrm{PO}_{4} \cdot 6 \mathrm{H}_{2} \mathrm{O}$ 結石片 を核としたものと同様に非晶質様物質の関與は作製標本 
上では, 明膫に認めることは出来なかつた.

グルクロン酸投與の 5 匹においては，捚入核たる Ca$\mathrm{C}_{2} \mathrm{O}_{4} \cdot \mathrm{H}_{2} \mathrm{O}$ 結石の溶解は 全然認められなかつたが, 非 投與群に比し, 異物結石形成を著明に阻止していた

(Fig. 4).

異物結石形成及び姉妹結石発生 学 重量平均值で 示す と，表 1 亿示す如くであり，尿酸結石片を核とせるもの を除き，グルクロン酸投與により異物結石形成は阻止さ れ, 又姉妹結石発生も非投與群に比べ少量である. 又非 投與群に掠ける異物結石形成及び姉妹結石発生注 $\mathrm{CaC}_{2}$ $\mathrm{O}_{4} \cdot \mathrm{H}_{2} \mathrm{O}$ 結石片を核とせるものの方が, $\mathrm{MgNH}_{4} \mathrm{PO}_{4}$ ・ $6 \mathrm{H}_{2} \mathrm{O}$ 結石片を核とするものより大きいようであるが, 反対にグルクロン酸投與群に招いては, $\mathrm{MgNH}_{4} \mathrm{PO}_{4}$ ・ $6 \mathrm{H}_{2} \mathrm{O}$ 結石片学核己せるものの方が, $\mathrm{CaC}_{2} \mathrm{O}_{4} \cdot \mathrm{H}_{2} \mathrm{O}$ 結石 片を核とせるものより少い. このととは，挿入核結石が $\mathrm{CaC}_{2} \mathrm{O}_{4} ・ \mathrm{H}_{2} \mathrm{O}$ である場合にはグルクロン酸投與による

第 2 表 $\mathrm{pH}$ の変動

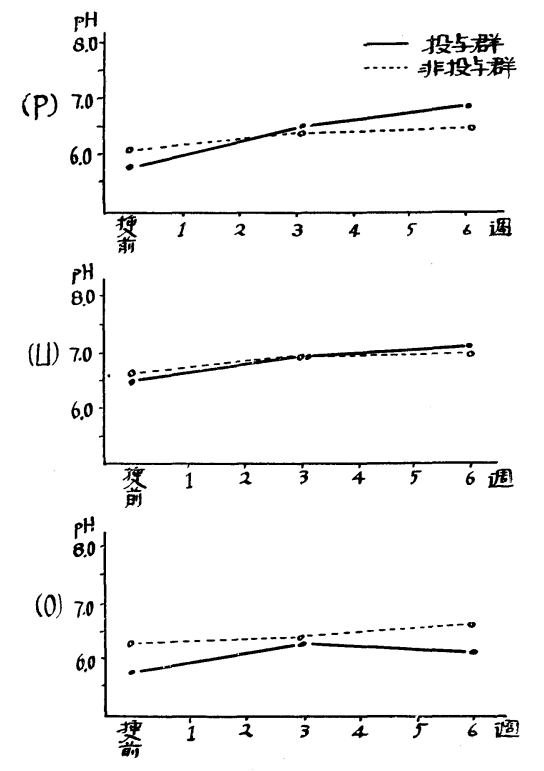

も, 核結石の溶解が涩められないが, $\mathrm{MgNH}_{4} \mathrm{PO}_{4} \cdot 6 \mathrm{H}_{2} \mathrm{O}$ の場合には, 多少溶解され, その上に異物結石形成があ ると考えるならば理解出来ることである。

実驗経過中の尿 $\mathrm{pH}$ 変動は表 2 , に示す如くであり, 僅かにアルカリ性に傾いたが, グルクロン酸投與群と非 投與群との間に有意の差は認められない. 又尿酸結石片 を核とせるものと他種の結石を核とせるものとの間にも 有意の差認められなかつた。

尿素分解菌感染は 3 例に認めたが（死亡例は不明）,
感染例はいずれも異物結石形成，姉妹結石発生共に，非 感染例に比べて著明であつた。

姉妹結石は非感染例に沶いても発生したが，グルクロ ン酸投與群においては, 発生なきもの多く（13匹中 5 匹 に発生), 発生しても少数であつた. か〉る姉妹結石はX 線粉末写真法により, $\mathrm{MgH}\left(\mathrm{PO}_{4}\right) \cdot 3 \mathrm{H}_{2} \mathrm{O}$ (Newberyite), でありててれは核結石の種類によらず同様であつた。 又姉妹結石の薄片標本を偏光顯微鏡的に観察する己， (Fig. 6) の如くで，結晶の集積塊の如く見られ，中心 安なす核物質, 或は非晶質様物質 (又心有機性物質) は 認め得なかつた。

2. X線粉末写真法による構成物質の決定

本項においては，ラットと共に家鬼についても检索し た. 即与家鬼を使用して, 種々の異物核を膀胱に手術的: に挿入し，形成異物結石を檢したが，家鬼はラツトと異 り尿道より自然排出されるものが多く, 雼に異物を膀胱 に固定する必要があり, 又異物結石形成もラツトにおけ る如く顯著ではなく, かつ相当長期間を要する. 絹糸, ネラトン及び人膀胱結石粉末 $\left(\mathrm{MgNH}_{4} \mathrm{PO}_{4} ・ 6 \mathrm{H}_{2} \mathrm{O}\right.$ 学主 成分とする) を合成樹脂で固化球狀にせるもの等を使用 したが, これらの異物結石を偏光智微鏡的に観察するに は不適当であり, 且つそれら異物膀胱結石により, 種々 の溶解郕 (乃至結石形成阻止剂) の影響を見るととは出 来なかつたが, 上記 3 異物に形成せられた異物結石の $\mathrm{X}$ 線粉末写真法学行い, いささか興味ある知見学得たので 附記する.動物実驗の方法, その他はラツトの場合と同 様であるが，ただ上記異物を膀胱頂部より適当の長さに 下垂し, 異物が常に尿に浸漬されるょうに絹糸の長さを 加減した. そのX線廻折の結果をラツトに招ける実驗と 共に述べる.

表 3 実験動物と生成された結石

\begin{tabular}{|c|c|c|c|c|}
\hline $\begin{array}{l}\text { 分析 } \\
\text { No. }\end{array}$ & 動物名 & 核 & 主 成 分 & 副 成 分 \\
\hline 1 & 家 鬼 & 綿 & $\begin{array}{l}\text { Struvite } \\
\text { Calcite }\end{array}$ & \\
\hline 2 & 家 航 & ネラトン & Calcite & $\begin{array}{l}\text { Brushite } \\
\text { Apatite? }\end{array}$ \\
\hline 7 & 家 香 & Struvite 結石球 & Calcite & Apatite \\
\hline 3 & ラット & 蓚酸結石片 & Newberyite & \\
\hline 4 & ラット & 同上の妹姉結石 & Newberyite & \\
\hline 5 & ラット & 尿酸結石片 & Newberyite & \\
\hline 6 & ラット & Struvite 結石片 & Struvite & \\
\hline
\end{tabular}

実驗的異物膀胱結石 7 例（ラット4, 家鬼 3 ）につい て, X線粉末写真法によつて構成物質を決定した結果は 
表 4 Newberyite を主とするラットの結石

\begin{tabular}{|c|c|c|c|c|c|c|c|}
\hline \multicolumn{4}{|c|}{ 分 } & \multicolumn{3}{|c|}{ No. } & \\
\hline \multicolumn{2}{|c|}{ (3) } & \multicolumn{2}{|c|}{$(4)$} & \multicolumn{2}{|c|}{$(5)$} & \multicolumn{2}{|c|}{ 文 献 值 $*$} \\
\hline $\mathrm{d}\left(\mathrm{A}^{\circ}\right)$ & $I^{* *}$ & $d\left(A^{\circ}\right)$ & $\mathrm{I} * *$ & $\mathrm{~d}\left(\mathrm{~A}^{\circ}\right)$ & $\mathrm{I}^{* *}$ & $\mathrm{~d}\left(\mathrm{~A}^{\circ}\right)$ & I** \\
\hline 5.98 & $\mathrm{~S}$ & 5.98 & $\mathrm{~S}$ & 6.00 & 5 & 5.9 & 0.40 \\
\hline 5.33 & M S & 5.37 & $\mathrm{M}$ & 5.35 & 3 & 5.3 & 0.20 \\
\hline 4.71 & $S$ & 4.65 & $S$ & 4.74 & 7 & 4.70 & 0.40 \\
\hline 4.51 & W & & & 4.48 & 2 & & \\
\hline 4.18 & $\mathrm{~S}$ & 4. 14 & $\mathrm{M}$ & 4.13 & 3 & 4.15 & 0.24 \\
\hline 3.63 & $\mathrm{~W}$ & 3.62 & MW & 3.67 & 1 & 3.64 & 0.08 \\
\hline 3.45 & S & 3.42 & $\mathrm{~S}$ & $\begin{array}{l}3.46 \\
3.19\end{array}$ & $\begin{array}{r}8 \\
1 / 2\end{array}$ & 3.45 & 1.00 \\
\hline 3.05 & $\mathrm{~S} \mathrm{~S}$ & 3.06 & S S & 3.05 & 10 & 3.05 & 0.80 \\
\hline 2.92 & $\mathrm{~W}$ & & & & & & \\
\hline 2.81 & M & 2.77 & $\mathrm{M}$ & 2.81 & 3 & 2.80 & 0.32 \\
\hline 2.70 & $M$ & 2.70 & W & 2.70 & 3 & 2.71 & 0.24 \\
\hline 2.58 & $\mathrm{M}$ & 2.56 & $M$ & 2.58 & 4 & 2.57 & 0.32 \\
\hline 2.51 & $\mathrm{~W}$ & & & 2.50 & $1 / 2$ & & \\
\hline 2.39 & $\mathrm{Mb}$ & 2.35 & $\mathrm{M}$ & 2.39 & $3 b$ & 2.39 & 0.24 \\
\hline
\end{tabular}

*4)鳥越論文を参照されたい。

** $\mathrm{CuINi}$, 強度は目測, S S 最強, $\mathrm{S}$ 強, M S や〉強, M中, MWや〉弱, W弱, b は幅広い線.

表 5 Calcite を主成分とする家鬼の結石

\begin{tabular}{|c|c|c|c|c|c|c|}
\hline \multicolumn{3}{|c|}{ 分 } & 析 & \multicolumn{2}{|c|}{ No. } & \multirow{3}{*}{ 不 純 物 } \\
\hline \multicolumn{2}{|c|}{$(2)$} & \multicolumn{2}{|c|}{$(7)$} & \multicolumn{2}{|c|}{ 天 Calcite $^{\text {然 } *}$} & \\
\hline $\mathrm{d}$ & I ** & $\mathrm{d}$ & I ** & $\mathrm{d}$ & $I^{*}$ & \\
\hline 7.56 & 1 & & & & & Brushite \\
\hline 4.23 & 2 & & & & & Brushite \\
\hline \multirow[t]{2}{*}{3.84} & 2 & 3.83 & 2 & 3.84 & 2 & \\
\hline & & 3.40 & $1 b$ & & & Apatite \\
\hline 3.02 & $10+$ & 3.03 & $10+$ & 3.02 & $10+$ & \\
\hline 2.83 & $1 / 2$ & 2.81 & $3 b$ & & & Apatite \\
\hline 2.63 & $1 / 2$ & & & & & Brushite \\
\hline 2.48 & 3 & 2.48 & 3 & 2. 49 & 3 & \\
\hline 2.28 & 7 & 2.28 & 7 & 2.28 & 7 & \\
\hline 2.09 & 5 & 2.09 & 5 & 2.09 & 5 & \\
\hline 1.907 & 7 & 1.910 & 7 & 1.912 & 7 & \\
\hline 1.860 & 7 & 1.868 & 7 & 1.870 & 7 & \\
\hline 1.597 & $2 b$ & 1.597 & 2 & 1.600 & 1. & \\
\hline 1.519 & 2 & 1.519 & 2 & 1.518 & 2 & \\
\hline
\end{tabular}

*岡山県川上郡山宝鉣山産.

$* * \mathrm{CuINi}$, 強度は目測, b は幅太い線.

表 3 の如くであつて, 決定に利用したデー夕は表 4, 表 5に示した.「X線粉末写真は後揭の如くであつて, 数 字は分析番号を示す. 即ち(3はラット苳酸塩結石に生じ
た異物結石，(4)は姉妹結石，(5)は尿酸結石片を核とした むのに生じた結石のX線粉末写真であり，(2)及び(7)は家 鬼に抬いてネラトン及び Struvite 結石球を核とした場 
合に生じた，Calcite を主成分とする異物結石のX線粉 末写真てある。」但し Struvite はすでに鳥越らによつ て報告された結果と大体一致しているので，乙れを主成 分とするものは省略した。表 3 から知られるととは, 家鬼怙よびラットの兩者に抬いて, $\mathrm{MgNH}_{4} \mathrm{PO}_{4} ・ 6 \mathrm{H}_{2} \mathrm{O}$ (Struvite) を主とする結石のできるとともあるが，家 鬼に括いては Calcite $\left(\mathrm{CaCO}_{3}\right)$, ラットでは Newberyite $\left(\mathrm{MgHPO}_{4} \cdot 3 \mathrm{H}_{2} \mathrm{O}\right)$ が特徵的な構成物質となつてい て，人間の結石と大いに様子を異にしている.

\section{IV 總括及び考按}

動物におる実驗的尿路結石の研究においては, その実 驗方法の如何を問わず，人間の尿路結石を比較研究する 場合, 結石形成に重点を置き, 形成せられた尿石自体に 対する考察は餘り行われていない. 殊に小動物に拉いて 生成せられた結石は, 微少な焉に, それらの定性或は定 量的分析は行われても, 構造乃至形成狀態に対する注意 は殆んぞ拂われておらない。

私は別稿) に怙いて人膀胱異物結石 4 例(クレオン,パ ラフィン, 鉄針, 草花の莖を核にしたもの) の構造につ き, 偏光㩆微鏡的に観察し, それら異物結石が主成分的 に殆んぞ, $\mathrm{MgNH}_{4} \mathrm{PO}_{4} \cdot 6 \mathrm{H}_{2} \mathrm{O}$ より成り, その内 1 例の 及 $\mathrm{CaC}_{2} \mathrm{O}_{4} \cdot \mathrm{H}_{2} \mathrm{O}$ を合んでいたてとを迅べたが, 上部 尿石が膀胱に落下せる場合, それを假に 1 個の異物と考 えるならば，膀胱結石の多くはその結石を核とした異物 結石と考えることが出来ると思われる．しかるに上部尿 石の主成分として最も多いものは鳥越らによれば, 苳酸 カルシウム, 次で $\mathrm{MgNH}_{4} \mathrm{PO}_{4} \cdot 6 \mathrm{H}_{2} \mathrm{O}$, Apatite, 尿酸の 順であり, 下部尿石は別稿() に掞いて述べた如く尿酸が 最も多く, 次で葆酸カルシウム, Apatite, $\mathrm{MgNH}_{4} \mathrm{PO}_{4}$ ・ $6 \mathrm{H}_{2} \mathrm{O}$ の順になる. この傾向は他の統計的交献でも大体 同じであるが, 反面, 膀胱結石の核部を構成する物質を 観察すると, 最も多いのは苳酸カルシウム, 次で Apatite, 尿酸の順になる.膀胱結石の大部分が上部尿石を 核としているこするならば，上記の事実は蓚酸カルシウ ムに掞いては首肯できるが, 他の物質構成は説明出来難 い. この理由は明かでないが, 次の如き推定も出来る.

即ち膀胱結石の発生機轉として模型圖で示せぼ

(1) 上部尿路結石 $\mathrm{A} か ゙$ 膀胱内に落下し, そのま>変化 溶解せずに Bなる結石成分が附加成長する，ての場合， $\mathrm{B}$ なる物質は $\mathrm{A}$ と同物質の場合と, 異質の場合の 2 つの 発育が考えられる。

(2) 上部尿路結石 $\mathrm{C}$ が膀胱内に落下し, 生体の條件な ぞにより溶解, 縮小し尿路外に排出される. 勿論, 变化

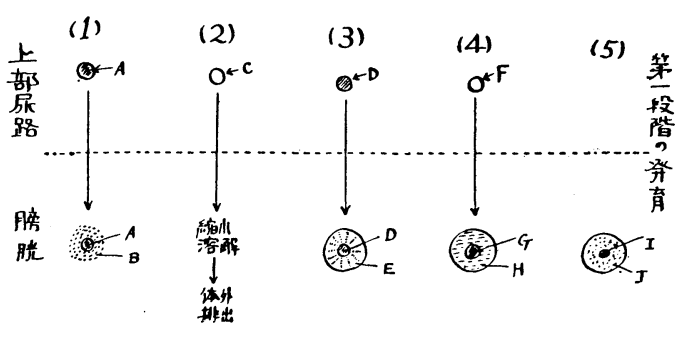

を受けるここなく，尿路外に排出される場合もある.

(3) 上部尿路結石 $\mathrm{D} か ゙$ 膀胱内に落下し, 生体の條件な ぞにより溶解，縮小するがその上に他の物質が沈着増大 乙膀胱結石を形成する。

(4) 上部尿路結石 $\mathrm{F}$ が膀胱内に落下し, 序々に Gなる 物質に変化・置換されつつ, 更にHなる成分が沈着し膀胱 結石が生成される，この場合，Hは Gと同質の場合と異 質の場合の 2 変化が考えられる。

(5) 上部尿路に由来しない膀胱性の異物 1 （たとえ ぼ，上皮，凝血塊，壊死組織片，外来異物等）に結石成 分丁が沈着成長し，膀胱結石を形成する。

以上の場合, 上部尿石はすべて單一な物質として考え たものであるが，実際には鳥越5)の報告にある如く，上 部尿石に扢いても苳酸カルシウム結石が他の結石の核と なることも多く，特に酸性燐酸カルシウム結石及び燐酸 アンモニウム・マグネシウム結石は蓚酸結石を核とする ことなど複雜であり，膀胱内に招ける発育を上部尿路に おける発育と区別することは出来難いが, 膀胱結石の構 造を観察し, その構成物質特に中心核部構成物質が上部 尿石と差異があること，又核を構成する結石が一部溶蝕 され，或は核を構成する物質が何か他の物質であつたも のが変化したと思われる観察例がかなりあり，しかもそ の発育は異質の物質が層狀に発育している例を多く認め たととなどより想定したものであつて，その根據は勿論 不充分であるが膀胱結石生成機轉上の 1 つの考え方を示 したものである。

本研究において, ラットの尿酸結石片を核とせるもの

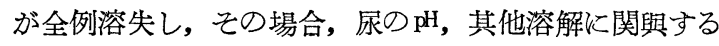
條件は餘り考えられぬととょり, 尿酸結石の如く, 新陳 代謝障害に由来すると考えられる結石は, 生体に根本的 なその障害がないか, あつても軽度の場合, 膀胱内にお いて溶解される可能性があるのではないか（即ち前述の (2)場合) と思われる (尿酸結石は別稿6)の溶解実驗で 溶解し難い結果を得ている). 
苳酸カルシウム結石片及び $\mathrm{MgNH}_{4} \mathrm{PO}_{4} \cdot 6 \mathrm{H}_{2} \mathrm{O}$ 結石片 に打ける結石形成狀態の観察では, 非晶質様物質の関與 柱標本上明膫には認め得ず, この点, 人間の膀胱異物結 石と異る所であり，このととは人尿結石片が異物として も他の異物と異り, 謂わば体内的異物であり, 他の体外 的異物の如き非晶質様物質の関與怔必要としないか, 必 要としても極めて少くてよいものと考えるならば, 人膀 胱結石の原発性なるか, 続発性なるかは, その核部構成 物質の種類と, 非晶質様物質の関與の狀態により推定出 来るかも知れないが, 更に研究を要するととである.

ラットに括ける異物結石の大きさは, 飼育日数と勿論 関係はあるが, それが一定限度以上に達すると膀胱容量 の点なぞより，それ以上増大することはなく，ての点よ り本研究に招ける観察は膀胱異物結石発育の第 1 段階を 観察し得たに過ぎないと思われ，人間の膀胱結石におり るが如き複雜な結石構造は認め得なかつたが, 姉妹結石 の発生は, 挿入核結石の種類の如何を問わず, Newberyite であり, その薄片標本の偏光顯微鏡的観察より明膫 な核は認め得ず，結晶の凝塊の如く観られ，又非晶質様 物質の関與が少い点なぞより，尿石生成の最初の段階に 結晶の沈溉を重峴し，有機性物質は必ずしも必要としな いと云う, Vermeulen ${ }^{6)}$, 中野7), Randal1 ${ }^{8)}$, Prien $^{9)}$, 等の説の可能性を支持出来るものである.

Vermeulen は実驗的異物膀胱結石の研究に敌いて, その結石成分が性及び種屬，又食䬣により異るものであ るとし, 叉 Paraffin, Polythene, Porcelain, Chalk, Charcoal, Fragment human stone, Lead, Zinc など 種々の核により異物結石形成に差異のあることを確かめ ている. 彼の形成異物結石の定量的分析結果では, $\mathrm{Mg}$ $\mathrm{NH}_{4} \mathrm{PO}_{4} ・ 6 \mathrm{H}_{2} \mathrm{O}$ が大部分を占めているが，森，加藤も $\mathrm{MgNH}_{4} \mathrm{PO}_{4} ・ 6 \mathrm{H}_{2} \mathrm{O}$ を定性分析より推断している. 又 Hedenberg, Engbelt ${ }^{10)}$ なごは, ビタミンA 欠乏により ラット膀胱に生じた 結石のX線廻折定行い, hydroxyl apatite であつたと述べているが, ラットの異物膀胱結 石に昖いて, Newberyite 学認めたものはない. Newberyite は人間に括いては, Struvite からの 2 次的変成 物として時々認められることは, 鳥越によつて報告され ているが，主成分をなす例は知られていない。

ラットの異物結石中, Struvite 結石片を核とするも のを除きすべて Newberyiteを主成分としていると そは，家鬼に打ける Calcite と同様に，動物実驗によつ て得られた結石が人間の結石と著しく異るものがあるこ とを示すものである。
Calcite が人尿結石中に存在するかどうかの問題は解 決困難であつて, 古くは定性分析により Calciteの存在 が屢々報告されたが, 最近のX線的研究, あるいは偏光 顯微鏡的研究では, 信頼出来るどの報告も Calciteの存 在を認めていない. 家鬼の分析例はわずか 3 例の及を X 線にとつたが， 3 例ともCalciteを主成分（絹糸を核と せる1例は Struvite を多量に含むが Calcite も主成分 となつている) としていることは注目值する。なお, Calcite のX線廻折の結果は, 天然産の Calcite とょく 一致しているが, Newberyite 結石のX線备折の結果 は, 結石相互及び文献值ともに互にやや，d, I, を異に している. 別種の鑛物とする湶ごの差ではないが, 不純 物の混入が豫想される. かかる不純物の混入去分明か にすることの出来ないのは, X線迴折の方法の久点の 1 つで, この点は将来, 化学分析その他で检討を要する.

結石発育抑制についてグルクロン酸の影響学眺める と, 尿石溶解に関する森の報告では, グルクロン酸が最 もすぐれた成績を示している.グルクロン酸の効果は, 投與により一部はその宗〉尿中に排泄され，カルシウム 塩の溶解度を上昇せしめ膠質を安定にし, 又抱合グルク ロン酸は更に一層, カルシウム塩の溶解性を増し, 之に 表面張力の減少による表面活性作用が加わるものとされ ているが, 私の実驗例では, $\mathrm{MgNH}_{4} \mathrm{PO}_{4} \cdot 6 \mathrm{H}_{2} \mathrm{O}$ 結石を 核としたものの一部に多少溶蝕されたと思われる例を認 めた他は，核結石に対する溶解性は認め得なかつたが, これは核として使用した尿石片の大さにもその一因があ ると思われる，しかし，グルクロン酸投與群は非投與群 に比し, 異物結石及び姉妹結石形成を著しく阻止してい た.グルクロン酸の Ca 含有結石に対する溶解作用は餘 り期待出来ぬが, 燐酸アンモニウム・マグネシウム結石 に対しては，それが小なる場合は増大阻止・乃至溶解上有 効と思われる. しかし乍ら, かつる藥郕の全身的投與に よつて, 溶解能が結石形成能を上迴るととを望むには, なお研究の餘地があると思われる。

\section{$\mathbf{V}$ 結 語}

ラットの実驗的異物膀胱結石による結石形成狀態を偏 光顯微鏡的に観察し, 家鬼の異物膀胱結石之共に, X線 粉末写真法により生成結石の決定を行つた. 又グルクロ ン酸をラツトに投與し, 異物結石形成に対する影響を檢 討した。

1）ラットの異物結石は燐酸アンモニウム・マグネシ ウム結石片を核としたもののみ, $\mathrm{MgNH}_{4} \mathrm{PO}_{4} ・ 6 \mathrm{H}_{2} \mathrm{O}$ （Struvite）が生じたが, 苳酸カルシウム結石片を核と 
したものに生じた異物結石及びすべての例に生じた姉妹 結石は Newberyite であり，又尿酸結石は全例が溶失 したが，一部少数例において，Newberyite 結石が生じ ていた.

2）家鬼膀胱異物結石はすべて Calciteを主成分と し，絹糸を核とせるもののみは Struvite をも主成分と していた。

3）グルクロン酸投與により，ラット膀胱異物結石形 成は著明に阻止し得たが，核とせる人尿結石の溶解には 殆んで影響を認め得なかつた。

稿を終るに際し, 恩師大村教授の御指導, 御校閲を深謝 する.併せて本研究に多大の御援助, 御指導を賜つた, 岡山大学理学部地学教室, 逸見助教授に感謝する。な拉 種々御教示, 御鞭撻下された鳥越博士に感謝する。

（本論交の要旨は第44回日本泌尿器科学会総会に於て 報告した。）

\section{主要參考文㱆}

1) Vermeulen, C.W. et al.: J. Urol., 64, 541 , 1950; ibid., 64, 549, 1950; ibid., 66, 1 , 1951; ibid., 66, 6, 1951; ibid., 68, 790, 1952; ibid., 69, 354, 1952; ibid., 72, 93,1954.

2) 森 : 泌紀要, $2,26,1956$.

3）加藤 : 泌紀要, 69, 354, 1955.

4）為政：日䎵尿会誌投稿中， 1957.

5）鳥越：日泌尿会誌, 46，190，1955；ibid., 46, $251,1955$.

6) 為政 : Acta medicine Okayama., Vol. 11, No. 4 投稿中.

7) Vermeulen, C.W.: A.M.A. Arch, Surg., 69 $759,1954$.

8）中野：皮泌誌, 24,1020 , 大13.

9) Randall, A.: Ann. Surg., 105, 1009, 1937.

10) Prien, E.L.: Surg. Gyne. Obst., 64, 201, 1937.

11) Hedenberg, I. et al.: Brit. J. Urol., 25, 33, 1953. 